\title{
Akdeniz Ekolojik Koşulları için Alternatif Bir Bitki: Crotalaria juncea L. (Krotalarya)
}

\section{Gülcan DEMIROĞLU TOPÇU1 ${ }^{\$}$, Şükrü Sezgi ÖZKAN² \\ 1,2Ege Üniversitesi Ziraat Fakültesi Tarla Bitkileri Bölümü, İzmir \\ ${ }^{1}$ https://orcid.org/0000-0002-5978-4183, ${ }^{2}$ https://orcid.org/0000-0001-5989-0384 \\ $\varangle$ : gulcan.demiroglu.topcu@ege.edu.tr}

\section{ÖZET}

Hayvanların sağlıklı bir şekilde beslenebilmesi için gerekli kaliteli kaba yem temini, hayvancılık işletmelerinin en önemli problemlerinden biridir. Değişik iklim, toprak ve üretim desenlerine sahip olan ülkemizin farklı bölgelerinde ve tarla koşullarında birçok yembitkisinin yetiştirilmesi sözkonusudur. Crotalaria juncea L.; önemli bir bitkisel protein kaynağı ve yem kalitesi etkileyici özelliğe sahip olan bir baklagil bitkisidir. Bitkinin yapraklarının \%30 oranında protein içerdiği bilinmektedir. Bunun yanı sıra; karışık veya alternatif ekimleri ile fikse edilen azotun buğdaygiller veya diğer familya bitkileri tarafından kullanılması önemli avantaj sağlamaktadır. Krotolarya bitkisinin organik maddesi, kısa sürede (yaklaşık 2 hafta) parçalanmaktadır ve en yüksek azot mineralizasyon hızının da bu zaman periyodunda gerçekleştiği bilinmektedir. Yaygın olarak yeşil gübre veya yem bitkisi olarak değerlendirilebilen tek yıllık, yazlık bir baklagil türü olan Crotalaria juncea L., pek çok ülkede farklı kullanım olanaklarına (yem, yeşil gübre, örtü bitkisi, lif, biyodizel vb.) sahiptir. Bu nedenle, ülkemiz için de ümitvar olabileceği düşünülerek yapılacak olan yeni bilimsel çalışmaların, bitkinin daha fazla tanınmasına ve öneminin giderek artmasına neden olacaktır. $\mathrm{Bu}$ literatür derlemesi, ülkemiz için tarımsal bir potansiyele sahip olabilecek Crotalaria juncea L. bitkisinin birçok yönü ile ele alınarak tanıtılmasını amaçlamaktadır.

\section{Derleme Makalesi}

\author{
Makale Tarihçesi \\ Geliş Tarihi : :20.11.2018 \\ Kabul Tarihi : 02.01.2019
}

\section{Anahtar Kelimeler}

Crotalaria juncea L.

Krotalarya

Akdeniz İklimi

Alternatif

Yem bitkisi

\section{An Alternative Crop for Mediterranean Climatic Conditions: Crotalaria juncea L. (Sunn hemp)}

\section{ABSTRACT}

To obtain quality roughage required for the healthy feeding of animals is one of the most important problems of livestock. Many forage crops are being grown in the different regions of our country which has different climate, soil and production patterns. Crotalaria juncea L. is a leguminous plant which is an important source of protein and has an impressive quality of forage crop. It is known that the leaves of the plant contain $30 \%$ protein. And also; the use of nitrogen fixed by sunn hemp through the gramineous or other family plants growing in mixture with sunn hemp provides them advantage. The organic matter of Crotalaria juncea L. is degraded in a short time (about 2 weeks) and the highest rate of nitrogen mineralization was known to occur during this period of time. Sunn hemp which generally can be evaluated as green manure or forage crop is an annual and summer leguminous plant and has different usage possibilities (forage, green manure, cover plant, fiber, biodiesel etc.) in many countries. In this regard, promising scientific studies in our country will help the plant to be more recognized and will increase its importance. This literature review aims to introduce this plant, an possible agricultural potential for our country, with many aspects.

\section{Review Article}

$\begin{array}{ll}\text { Article History } \\ \text { Received } & : 20.11 .2018 \\ \text { Accepted } & : 02.01 .2019\end{array}$

Keywords

Crotalaria juncea L.

Sunn Hemp

Mediterranean Climate

Alternative

Forage Crop

To Cite : Demiroğlu Topcu G, Özkan ŞS 2019. Akdeniz Ekolojik Koşulları için Alternatif Bir Bitki: Crotalaria juncea L. (Krotalarya). KSÜ Tarım ve Doğa Derg 22(2): 339-345. DOI: 10.18016/ksutarimdoga.vi.485713. 


\section{GİRIŞ}

Crotalaria cinsi, Katırtırnağı Benzerleri Oymağı (Genisteaea)'ndan olup, yaklaşık 600 adet türü kapsamaktadır. Cins adı olan Crotalaria, çıngırak anlamına gelmekte ve olgunlaşmış baklalarda tohumların çıkardığı gürültüyü ifade etmektedir (White ve Haun, 1965). Bu cinsin türleri tropikal, subtropikal ve daha az ılıman bölgelerde yayılış göstermekte ve ılıman bölgelerde deniz seviyesinden 600 metre yüksekliğin altında kalan yörelerde yetiştirilebilmektedir. Crotalaria juncea L., Fabaceae familyasına ait, farklı kullanım olanaklarına sahip ve Dünya'da birçok ülkede yetiştirilen yıllık bir bitkidir. $\mathrm{Bu}$ cinse ait önemli olan diğer türleri ise Çizgili Krotalarya (Crotalaria striata), Süslü Krotalarya (Crotalaria spectabilis), İnceyaprakl Krotalarya (Crotalaria intermedia) ve Mizrakyapraklı Krotalarya (Crotalaria lanceolata) oluşturmaktadır. Bu türler, başta Amerika Birleşik Devletleri olmak üzere, çeşitli ülkelerde hem toprak koruma ve ıslahı amacıyla, hem de yem bitkisi olarak uzun yıllardır yetiştirilmektedir (Ahlgren, 1956).

Crotalaria cinsinin en önemli türü olan ve Bengal Kendiri ya da Bombay Kendiri adı ile bilinen Crotalaria juncea L., genel olarak Hindistan'a özgü bir bitki olarak kabul edilmekte ve toprak ıslahı, lif üretimi ve yem bitkisi olarak kullanılmaktadır. Tropik bölgelerde, özellikle Endonezya, Malezya, Tayvan, Tayland ve Çin'de, yoğun olarak yeşil gübre bitkisi olarak yetiştirilmektedir. Güney Asya ülkelerinde ise eski yüzyıllardan beri önemli lif bitkilerinden biri olup, halat ve kâğıt yapımında kullanılmaktadır (Rotar ve Joy, 1983).

\section{Bitkisel Özellikleri}

Crotalaria juncea L., yaygin olarak tropik bölgelerde yetişen, 2.5-4 metre boylanabilen uzun boylu, dik gövdeli ve tek yıllık otsu bir bitkidir. Uzunlamasına mızrak şeklinde olan yapraklar, basit yapıda ve sap boyunca spiral olarak dizilmiş olup, $0.5-3.0 \mathrm{~cm}$ genişliğinde, 4-12 cm uzunluğunda ve parlak yeşil renktedir. Bitki, güçlü kazık kök ve çok iyi gelişmiş yan köklere sahiptir. Sap çapı, $2 \mathrm{~cm}$ kalınlığında olabilmektedir. Kısa gün dönemi altında yetiştirildiğinde çiçeklenme ekimden itibaren yaklaşık 8 hafta sürer. Çiçek, $8-20 \mathrm{~cm}$ uzunluğunda ve salkım şeklinde; çanak yaprak $1.5 \mathrm{~cm}$ uzunluğunda ve tüylü; taç yaprak ise 2-5 cm uzunluğunda ve parlak sarı renktedir. Meyve, silindirik bakla şeklinde, kısa kadifemsi tüylü, 6-12 tohum içermekte; tohumlar eğri kalp şeklinde 6-7 mm uzunlukta ve koyu kahverengisiyah renkte olabilmektedir. Tohumlarının bin dane ağırlığı 35-50 gram civarındadır (Rotar ve Joy, 1983; Chaudhury ve ark., 1997; Mosjidis ve Wang, 2011; AlSnafi, 2016; Demiroğlu Topçu ve Özkan, 2018).

\section{Yetiştiriciliği}

Crotalaria cinsinin en hızlı büyüyen türü olan Crotalaria juncea L. hem tropik hem de sub-tropik iklime adaptasyonu oldukça yüksektir. Ilıman bölgelerde deniz seviyesinden 600 metre yüksekliğin altında kalan bölgelerde yetiştirilebilmektedir (Rotar ve Joy, 1983). Ayrıca, her türlü toprak koşullarına uyum sağlayabilmektedir. Yıllık ortalama sıcaklığın $15.0-37.5^{\circ} \mathrm{C}$ arasinda ve toprak pH'nın 5.0-8.4 arasında olduğu topraklarda başarıyla yetiştirilebilmektedir. Tohum çimlenmesini sağlamak amacıyla iyi hazırlanmış bir tohum yatağına ekim yapılmalı ve toprak nemi \%30'un altında olmamalıdır. Ekim zamanı, Crotalaria juncea L.'in vejetatif büyüme ve gelişimini doğrudan etkilemektedir. Kısa gün bitkisi olmasına karşın, vejetatif büyüme uzun gün periyodunda daha avantajlıdır. En iyi büyüme Nisan ve Mayıs aylarında ekimleri yapılan bitkilerden elde edilmektedir. Geç yapılan ekimlerde, vejetatif büyüme periyodu kısalırken, bitki boyuda kısalmakta, internodi sayısı azalmakta ve sap çapı daralmaktadır. Yeşil gübre amacıyla ekim yapılacaksa bitki yetişme döneminin 30 veya 45 . gününde toprağa gömülecek şekilde herhangi bir ayda ekim yapılabilir. Crotalaria juncea L.'in siraya ekilmesi önerilmektedir. Normal şartlarda tohumlar 2-3 cm derinliğe ekilmektedir. Yapılan araştırmalar, Crotalaria juncea L.'nın dar sıralara ekiminde geniş sıralara oranla daha yüksek tohum verimine ulaştığını göstermektedir. $\mathrm{Bu}$ nedenle, $20-30 \mathrm{~cm}$ sira aralığ mesafe, tercihe göre gerekirse tekleme yoluyla $5-10 \mathrm{~cm}$ arasında tutulmalıdır. Çimlenme epigealdir ve tohum yaklaşık 3 gün içerisinde çimlenmektedir. Bitki büyümesi ekim tarihinden ve bitkinin erken dönemindeki yağışlardan çok fazla etkilenmektedir. Tohumluk oranı, çimlenme ve toprak nemine bağlıdır. Tohumluğun çimlenme yüzdesi en az \%80 olmalı ve siraya ekimlerde $2-3 \mathrm{~kg} \mathrm{da}^{-1}$, serpme ekimlerde ise 4-5 $\mathrm{kg} \mathrm{da}^{-1}$ tohumluk kullanılmalıdır. Bitkinin serpme ekimlerinde yabancı otlar daha rahat baskılanabilmektedir. Genel olarak yabancı ot mücadelesi yapılmamaktadır. Fakat Crotalaria juncea L. ile aynı sürede gelişen Ipomoea spp. dikkat edilmelidir. Baklagil familyasına ait bir bitki olması nedeniyle, yetiştiriciliğinde azot gübrelemesine ihtiyaç duymamasına rağmen, ekimle birlikte bir miktar azotlu gübreleme yapılması verim artışına yardımcı olmaktadır.

Bitkinin hasat zamanı; yetiştirilen ekolojiye ve yetiştirilme amacına göre farklılıklar göstermektedir. Yeşil yem veya silaj yapımında değerlendirilmek istendiğinde, verim ve kalite açısından en uygun hasat döneminin \%50 çiçeklenme ve erken bakla aşaması olduğunu göstermektedir. Hasat toprak seviyesinden orak veya makine yardımı ile yapılabilmektedir. Ayrıca, bu dönemde Dünya'da bazı ülkelerde otlatılarak da değerlendirilmektedir. 
Lif için, yeterli miktarda nem tutan, kumlu veya tınlı yapıya sahip, oldukça hafif ve iyi drene edilmiş topraklarda yetiştirilmesi önerilmektedir. Çiçeklenmede veya tohum kabukları tamamen olgunlaştığında hasat edilmesi gerekmektedir. $\mathrm{Bu}$ dönemde mukavemet ve lif kalitesinde çok az fark olduğu belirtilmektedir. Ayrıca, bazı bölgelerde ise bitkinin üst kısmı (yaklaşık $30 \mathrm{~cm}$ ) önce üstten biçilerek yem için kullanılmaktadır. Hasattan sonra bitkiler boy ve kalınlıklarına göre gruplanarak yaklaşık 20-25 cm'lik demetler halinde birleştirilmekte ve oluşturulan demetler yaprak dökmek amaciyla 2-3 gün tarlada bekletilmektedir. Daha sonra, yaprak elle uzaklaştırılmakta ve saplar direk havuzlamaya gönderilmektedir. Hindistan'da bazı bölgelerde, bitkiler 10-15 gün boyunca yerde bırakılmakta ve liflerin ayrılma işlemi, gece boyunca oldukça ağır olan yeterli çiğ sayesinde gerçekleşmektedir.

Bitkinin tohum verimi, ekim zamanına, çeşidine, hastalıkların ve zararlıların etkisine bağlı olarak oldukça değişkenlik göstermektedir. Tohum üretimi için seçilen bölgede tercihen; enlem $24^{\circ} \mathrm{N}$ 'nin altında kalmalı, sıcaklık $10^{\circ} \mathrm{C}$ 'nin altına düşmemeli, iyi güneş ışığ almalı ve meyve verme sırasinda yağış olmamalıdır. Hindistan'da yetiştirme alanları $17-30^{\circ} \mathrm{N}$ arasındadır. Brezilya'da ise, orta ve şiddetli yağış koşullarında, ekvatoral kuşaktan $22.5^{\circ} \mathrm{N}$ kadar yetiştirilebilmektedir. Optimum koşullarda ortalama tohum verimi $30^{-} 70 \mathrm{~kg} \mathrm{da}^{-1}$ 'dır.

Crotalaria juncea L., Akdeniz iklimi etkisi altındaki Bornova/İzmir koşullarında yer alan Ege Üniversitesi Ziraat Fakültesi Tarla Bitkileri Bölümü'ne ait arazilerde ön denemelere alınmış ve ülkemizde hem yeşil yem olarak hem de tohum üretimi amaciyla başarı ile yetiştiriciliğinin gerçekleştirilebileceği kanaatine varılmıştır (Demiroğlu Topçu ve Özkan, 2018) (Şekil 1).

\section{Kullanım Alanları}

ABD'de ilk araştırmaların 1930'lu yıllarda başladığı bilinmektedir (Cook ve White, 1996). Crotalaria juncea L. bitkisi ile ilgili yapılan geçmiş yıllardaki araştırmalarda, genellikle tohumlarının veya yem bitkisi olarak değerlendirilen yeşil aksamlarının hayvan beslenmesinde toksik etki yaratabileceği ile ilgili ifadeler yer almaktadır. Ancak, son yıllarda yapılan araştırmalar ve yeni geliştirilen çeşitlerin toksik etki yaratmadığı kanıtlanmıştır (National Academy of Science, 1979; Purseglove, 1981; Rotar ve Joy, 1983; Williams ve Molyneux, 1987; Strickland ve ark., 1987; Hess ve Mosjidis, 2008; Mosjidis ve ark., 2012). Buna karşın, sadece aynı cinse ait Crotalaria spectabilis, Crotalaria retusa ve Crotalaria pallida türlerinin toksik olduğu bazı araştırıcılar tarafından kesin olarak saptanmıştır (Ritchey ve ark., 1941; Martin ve ark., 1976; Hooper ve Scanlan, 1977;
Williams ve Molyneux, 1987).

Purseglove (1981), Crotalaria juncea L.'nın tohumlarının bazı ülkelerde çiftlik hayvanlarına toksik etkilere yol açmadan yem olarak kullanılabildiğini bildirmektedir. Rotar ve Joy (1983) ise Hawaii'de geliştirilen "Tropic Sun" çeşidinin tohumlarının hayvanları toksik olmadığını belirlemişlerdir. Williams ve Molyneux (1987) tarafından birkaç Crotalaria türünün tohumlarının toksik etkilerini belirlemek için civcivler üzerinde yürütülen bir çalışmada, $10 \mathrm{mg} \mathrm{g}^{-1}$ vücut ağırlığı ile beslenen tavuklarda Crotalaria juncea L.'nın tohumlarının herhangi bir toksik etkisinin olmadığ saptanmıştır. Mosjidis ve ark. (2012), tropik bölgelerde yaygin olarak yetişen ve tek yıllık bir tür olan Crotalaria juncea L. bitkisinin tohumlarinin ve yeminin toksik etki yapıp yapmadığını araştırdıkları çalışmalarının sonuçlarında, bu bitkinin değerli bir yem kaynağı olduğunu (toksik etkisi olmayan) ortaya koymuşlardır. Tohumlarının evcil hayvanlarda akut toksisiteye neden olmadığını, ancak eser miktarda pyrolizidin alkoloidinin bulunduğu anlaşılmıştır. $\mathrm{Bu}$ yüzden, yemleme ve yem olarak değerlendirilmesinde herhangi bir problem yaratmayacağı bildirilmektedir. Crotalaria juncea L., kendi cinsi içinde en agresif tür olarak bilinmektedir (Mosjidis ve Wang, 2011). Ayrıca, 60 günde $2.700 \mathrm{~kg} \mathrm{da}^{-1}$ yeşil ot verimine ulaşabilmekte (Warren ve ark., 2012) ve hızlı gelişen bitkinin ekimden 60 gün sonra 1.2 metre ve 90 gün sonunda da 1.8 metre ulaştığını belirtilmektedir (Rotar ve Joy, 1983; Mansoer ve ark., 1997). Bitkinin yapraklarının ise \%30 oranında protein içerdiği bilinmektedir (Warren ve ark., 2012).

Ayrica Mansoer ve ark. (1997) yaptıkları bir çalışmada, her hasat zamanında yapraklardaki lignin, selüloz ve hemiselüloz oranlarının, saptaki oranlarından daha düşük olduğunu bildirmişlerdir. Koyun ve keçilerin bitkinin yapraklarını ve üst kısımlarını tercih ettiği gözlemlenmiştir (Burke ve ark., 2011). Otlatma bitkiler yaklaşık $45-90 \mathrm{~cm}$ uzunluğa geldiğinde başlatılabilmektedir. Yaprak kalitesi yüksek (yaklaşık \%4-5 N eşdeğeri \%25-30 protein, \%22-28 NDF, \%22-27 ADF) sap kalitesi düşük (yaklaşık \%1.3-1.7 N eşdeğeri \%8-10 protein, \%74-76 $\mathrm{NDF}$ \% \%4-65 ADF) olmasina rağmen saplar ruminantların ihtiyaç duyduğu kaba yemi sağlayabilmektedir. Yoğun bir büyüme çiçeklenmeye kadar alt yaprakların bazılarının kaybolmasina ve yem kalitesinin düşmesine sebep olabilir. Bitki \%80 çiçeklendiğinde yaklaşık \%35-40 biyokütle yapraklardan oluşmaktadır. Sonuç olarak erken hasat yem kullanımı için daha iyidir çünkü bitkiler daha az olgunlaşır ve yemde yaprak oranı artacağı için yem kalitesi artar. Ayrica, Crotalaria juncea L. silaj yapımında da başarılı sonuçlar vermektedir (Coutinho ve ark., 2011). 


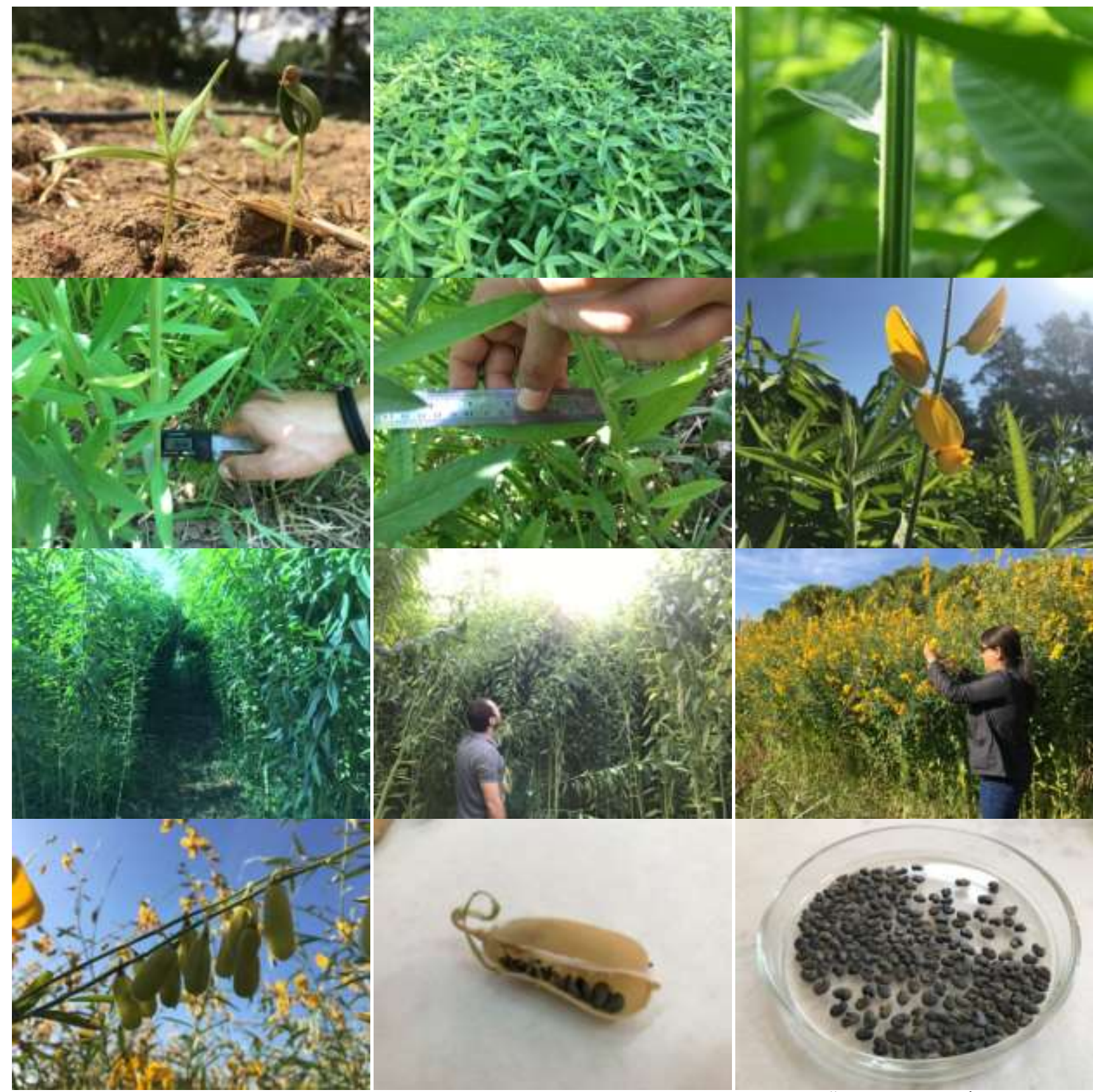

Şekil 1. Crotalaria juncea L. bitkisine ait bazı tanıtıcı fotoğraflar (Ege Üniversitesi, İzmir)

Hayvanal üretimde en önemli girdi olan yemlerin sağlanmasında başlıca kaynak; yem kalitesini arttırmada ciddi öneme sahip olan, proteince zengin baklagil yem bitkileridir. Bu bitkiler yalnızca hayvan beslemede değil, köklerinde ki Rhizobium bakterileri aracılığıyla havadaki serbest azotu toprağa bağlarak, toprak yapısını iyileştirmenin yanı sıra münavebede kullanılabilmesi ile de kendinden sonra yetiştirilecek kültür bitkisinin verim ve kalitesinde artış sağlaması dolayısıyla da ciddi bir öneme sahiptir. Baklagil yem bitkilerinin toprağa bağladığı azot, karışık ekimlerde, karışım içindeki azot fiksasyonu yapamayan bitkiler için önemli bir azot kaynağ oluşturmaktadı. (Duke, 1981; Lindemann ve Glover, 2003). Yapılan araştırmalar, adi fiğ (Vicia sativa)'in $18 \mathrm{~kg} \mathrm{da}^{-1}$, tüylü fiğ (Vicia villosa)'in ise $11 \mathrm{~kg} \mathrm{da} \mathrm{da}^{-1}$ azotu fikse edebildiğini göstermektedir (Erkovan, 2007). Toprağ iyileştirme özelliği ile de ön plana çıkan ve yazlık olarak yetiştirilebilen Crotalaria juncea L. bitkisinin ise toprağa sağladığı azot miktarının $16.5 \mathrm{~kg} \mathrm{da}^{-1} \mathrm{~N}$ olduğu saptanmıştır (Rotar ve Joy, 1983).Kısa sürede gelişme gösteren yazlık bir bitki için bu değer oldukça tatmin edici olduğu düşünülmektedir.

Crotalaria juncea L. organik maddesi, tropikal iklimlerde kısa sürede (yaklaşık 2 hafta) parçalanmaktadır ve en yüksek azot mineralizasyon hızının da bu zaman periyodunda gerçekleştiği bilinmektedir (Wang ve ark., 2004). Bu nedenle, üreticiler Crotalaria juncea L.'nın toprağa karıştırılmasından sonraki 2 hafta içerisinde besin maddeleri alıma hazır olacak şekilde ekim ve gübre uygulamalarını düzenlemelidir. Alternatif olarak, 
Crotalaria juncea L. artıkları organik malç olarak toprak yüzeyine bırakılabilmektedir. Bu malç; çok daha yavaş ve daha uzun bir sürede ayrışma göstermektedir. Crotalaria juncea L. bitkisinin parçalanmış artıklarının yüzey malçı olarak şeritsel toprak işleme sisteminde kullanımı, bazı artıkların toprağa dahil edilmesine ve besin maddelerini hemen serbest birakmasına izin verirken, bazı artıkların ise toprak yüzeyinde kalarak besin maddelerini daha uzun bir sürede serbest birakacak şekilde malç olarak kullanabilmesine olarak tanımaktadır (Reeves ve ark., 1996).

Türkiye'de ekim nöbeti sistemlerinde yaygın olarak uygulanan mısır-buğday yetiştiriciliğinde, bitkilerden alınan verimin arttırılabilmesi için yüksek oranda azotlu gübre kullanılmaktadır. Kullanılan bu azotlu gübre yağışlar ve sulama suyu ile beraber yeraltı sularına karışarak çevre ve su kirliliğine neden olabilmektedir. Kontrolsüz ve bilinçsizce kimyasal içerikli azotlu gübre kullanımın yol açtığg bu sorunlar dikkate alındıgında, ekim nöbeti ve yeşil gübreleme gibi çevreye karşı olumsuz etkisi olmayan tarımsal uygulamalar önem kazanmaktadır. Bu uygulamalar için ise toprağa azot kazandıran ve organik madde artışı sağlayan baklagiller en uygun bitkilerdir. Özellikle yeşil gübreleme uygulamasında toprak üstü organların toprağa karıştırılmasıyla mevcut organik madde miktarının da artması sağlanmaktadır. Ayrıca, ot temini sıkıntısının yaşandığı dönemlerde, yeşil gübre bitkilerinin yeşil ot amacıyla biçildikten sonra geriye kalan bitki kısımlarının toprağa karıştırılması ile de yeşil gübreleme uygulaması yapılabilmektedir (Açıkgöz, 2001; Karakurt, 2009). Crotalaria juncea L. yeşil gübre olarak dünyada yaygin şekilde yetiştirilmektedir (Diamond, 2006). Uygun toprak koşullarında, Crotalaria juncea L. birçok bitki için gerekli N, P, K besin gereksinimlerinin çoğunu karşılayabilecek yeterli gübreyi sağlayabilmektedir (Phatak ve ark., 2002). Azot ve diğer makro besin elementlerinin çoğu, yapraklarında bulunduğu için, yeşil gübre veya malç olarak Crotalaria juncea L. toprağa karıştırılmak istendiğinde, erken veya orta çiçeklenme dönemi en uygun olmaktadır (Marshall, 2002). Güney Afrika, Brezilya ve Hawaii gibi Dünya'nın diğer bölgelerinde çoğunlukla yeşil gübre ve örtü bitkisi olarak yetiştirilmektedir (Romin ve Fitt, 1938; National Academy of Science, 1979; Rotar ve Joy, 1983; Stallings, 2015; Meagher ve ark., 2017). Hizlı gelişme yeteneğine sahip olan Crotalaria juncea L. bitkisi, potansiyel kullanımı ve yararları arttırılması için National Academy of Science (1979) tarafindan ıslah programına dâhil edilmiştir.

Ekim nöbeti sistemleri içerisinde Crotalaria juncea L.'nın en önemli avantajı bir baklagil bitkisi olarak havadaki serbest azotu kök nodüllerinde bulunan bakteriler tarafından sabitleyebilmesi sonucu azot ihtiyacını karşılama ve toprak yenilemesi için iyi bir potansiyele sahip olmasıdır. Ayrıca, nematod enfeksiyonuna maruz kalan alanlarda rotasyonda yararlıdır (Wang ve ark., 2002; Kamil ve ark., 2009). Şeker kamışı, çeltik, buğday ve jüt gibi bitkilerle rotasyon denemeleri yapılmıştır (Barros Salgado ve ark., 1972). Küba'da kenaf ve A.B.D.'de pamuk ile ekim nöbetine girmektedir. Brezilya'da, buğday, sorgum, şeker kamışı ve fasulye ile nöbetleşe ekilmektedir. Fasulyeden önce ekilen Crotalaria juncea L. bitkisinin, verimi ortalama \%41 oranında arttırdığ $\breve{1}_{1}$ belirlenmiştir. Hindistan'da uygun bulunan ekim düzenleri; krotalarya-buğday, krotalaryapatates, krotalarya-çeltik-buğday, krotalarya-hardal, krotalarya-hardal-buğday şeklindedir. Çeşitli kombinasyonlar üzerine yapılan çalışmalarda, ön bitki olarak ekilen Krotalarya bitkisinin buğdayın verimini \%10-15 arttırdığı tespit edilmiştir (Chaudhury ve ark., 1997).

Crotalaria juncea L., hızlı büyüyen, toprağa azot sağlayan ve örtü bitkisi olarak yararlanılabilen baklagil yem bitkisidir. Ayrıca, yeşil gübre olarak da Dünya'da yaygın şekilde yetiştirilmektedir (Schomberg ve ark., 2007). Bitki uygun koşullar altında $15.0-16.5 \mathrm{~kg} \mathrm{da}^{-1}$ azot üreten ve yüksek miktarda biyokütle (2 aylık dönemde $700 \mathrm{~kg} \mathrm{da}^{-1} \mathrm{kuru}$ madde) meydana getirebilen, tropik ve subtropik ortamlara adapte olmuş bir türdür (Rotar ve Joy, 1983). Bitkinin yabancı bitkileri bastırma gücü çok yüksek olmakla beraber, erozyon kontrolünde de önemli yer almaktadır. Crotalaria juncea L. yaprakları fitotoksik protein olmayan amino asit hydroxynorleucin içerdiği için yabancı otlarla rekabetinde etkili olduğu bilinmektedir (Pilbeam ve Bell, 1979; Javaid ve ark., 2012; Morris ve ark., 2015).

Crotalaria juncea L. lifi oldukça güçlü ve tuzlu suya dayanıklıdır. Halat, ip ve balık ağı yapımında kullanılabilmektedir (Dempsey, 1975). Crotalaria juncea L. lifinden, İngiltere'de sicim, paspas, branda, ayakkabı tabanı, sandalet ve deniz kordonları üretilmektedir. Ayrıca, kilim, halı, masa ve yatak çarşafları gibi ürünlerde kullanılmaktadır (Gilbert, 1966). Geniş bir kullanım yelpazesi için uygun görülen yüksek bir hamur verimine sahip olmasından dolayı, bitkinin kuru sapları kâğıt endüstrisi için yeni bir ekonomik ürün sağlayabilme potansiyeline sahiptir (Field, 1992; Sarkar ve ark., 2015).

Dünya'da bitkisel üretim yalnızca gıda temini amacıyla gerçekleştirilmemekte, bitkilerden enerji üretimi de giderek önem kazanmaktadır. Biyoyakıt eldesinde kullanılabilecek bitkilerin, özellikle marjinal alanlarda yetiştirilebilme olanakları üzerine çalışmalar yapılmaktadır. $\mathrm{Bu}$ sayede, tarımda kullanılamayan bu alanların ekonomiye katkısının sağlanması düşünülmektedir. Günümüzde, toplam tarımsal üretim içerisindeki yem bitkileri tarımının $\% 30$, enerji bitkileri tarımının ise $\% 20$ seviyelerine çıkarılması hedeflenmektedir (Eser ve ark., 2007). 
Temiz biyodizel, biyokütle temelli tarımsal yağlardan üretilebilmektedir. Crotalaria juncea L.; birçok ülkede yetiştirilebilen, baklagiller familyasına ait ve yeşil gübre veya yem bitkisi olarak değerlendirilebilen çok yönlü bir bitki olması yanında, tohumundan elde edilen biyoyağ ile metanol ve farkl katalizörler kullanılarak transesterifikasyonla biyodizel de üretilebilmektedir (Sadhukhan ve Sarkar, 2016). Crotalaria juncea L. yağının enerji içeriği (34.128 MJ $\mathrm{kg}^{-1}$ ), benzin (47 MJ kg-1) ve dizel yakittan (44.8 MJ kg1) biraz daha düşük olmasına rağmen diğer özellikleri kullanım için büyük bir potansiyele sahip olduğunu göstermektedir. $\mathrm{Bu}$ biyolojik yağ, bazı modifikasyonlarla (katkı maddeleri) bir dizel motor için yakıt olarak kullanılabilme olasılığı taşımaktadır (Demiroğlu Topçu ve ark., 2017).

\section{SONUÇ}

Hayvancılık faaliyetlerinin sağlıklı bir şekilde yürütülebilmesi için gerekli kaliteli kaba yem temini, işletmelerin en önemli sorunlarından birisidir. Hayvancılıkta masrafların ortalama \%70'inin yem giderlerinden oluştuğu göz önüne alındığında ve günümüzde ülkemizde özellikle et fiyatlarının ulaştığı nokta da düşünüldüğünde, kaliteli kaba yem üretiminin ne kadar önemli olduğu ortaya çıkmaktadır. Ülkemizde Akdeniz İklimi hâkim yörelerimizde; bilinen ve Dünya'da yaygın olarak kullanılan pek çok bitkinin başarıyla yetiştirilmesi olasıdır. Tek yıllık, yazlık bir baklagil türü olan Crotalaria juncea L. bitkisinin, farklı kullanım olanakları nedeniyle ümitvar potansiyeli olduğu düşünülmektedir. Crotalaria juncea L.'nın olası potansiyelleri göz önüne alındığında, bu literatür derlemesinin ülkemizde yapılacak yeni bilimsel araştırmalara ışık tutması beklenmekte ve bu bitkinin ülke tarımına kazandırılması gerektiği düşünülmektedir.

\section{KAYNAKLAR}

Açıkgöz E 2001. Yem Bitkileri. Uludağ Üniv. Güçlendirme Vakfı Yayın No:182, Vipaş A.Ş. Yayın No:58, Bursa.

Ahlgren HG 1956. Forage Crops. Department of Farm Crops Rutgers University, Mc. Graw-Hill Book Company Inc., 2nd Edition, New York-USA.

Al-Snafi AE 2016. The contents and pharmacology of Crotalaria juncea-A review. Volume 6, Issue 6 Version. 2, PP. 77-86.

Barros Salgado AL, Lovadini LAC, Pimental M, Gimenez W 1972. Instrucoes para a cultura da Crotalaria juncea. Instituto Agronomico, Campinas, Brazil. Secao de Plantas Fibrosas Boletim 198.

Burke JM, Mosjidis JA, Miller JE, Casey P 2011. Sunn hemp with chicory or pearl millet to minimize gastrointestinal nematode infection in weaned goats. J. Anim. Sci. 89(E-Suppl.2):17-18 (Abstr.).

Chaudhury J, Singh DP, Hazra SK 1997. Sunnhemp (Crotalaria juncea L.). Central Research Institute for Jute and Allied Fibres (ICAR), Tech. Bull. No. 5, pp 1-50.

Cook CG, White GA 1996. Crotalaria juncea: A potential multipurpose fiber crop. p. 389-394. In J. Janick (ed.), Progress in new crops. ASHS Press, Arlington, VA.

Coutinho JJO, Coura RAN, Athayde AAR 2015. Effect of additives in the forage legumes silage. Ciência et Praxis, V. 8, N. 15., 53-57.

Demiroğlu Topçu G, Özkan ŞS 2018. A Preliminary Study on The Adaptation of Sunn Hemp (Crotalaria juncea L.) In Mediterranean Climatic Conditions, 2nd International Vocational Science Symposium, 26-29 April 2018, Abstract Book, Pp:199, Antalya/Turkey.

Demiroğlu Topçu G, Özkan ŞS, Özçelik AE, Acaroğlu M 2017. Investigation of Agronomic Techniques of Sunn Hemp (Crotalaria juncea L.) as an Alternative Forage and Energy Crop in Turkey, 1st International Conference on Energy and Thermal Engineering, 25-28 April 2017, Proceedings Book, $\mathrm{Pp}: 333$, Istanbul/Turkey.

Dempsey JM 1975. Fibre Crops. The University Press of Florida. Gainesville.

Diamond H 2006. Traits of Crotalaria used as a green manure legume on sustainable cropping system. JARQ, 40(4): 299-305.

Duke JA 1981. Handbook of Legumes of World Importance. Plenum Press: New York, NY.

Erkovan HI 2007. Baklagil-Buğdaygil Yembitkileri Karışımlarında Simbiyotik Azot Fiksasyonu ve Transferinin Tespiti, Tarla Bitkileri 7. Kongresi, Cilt:2, 268-271, Erzurum.

Eser V, Sarsu F, Altunkaya M 2007. Biyoyakıt Üretiminde Kullanılan Bitkilerin Mevcut Durumu ve Geleceği. Biyoyakıtlar ve Biyoyakıt Teknolojileri Sempozyumu, 51-61, Ankara.

Field D 1992. Papermaking in India, Bangladesh and the Himalayas-An overview. Hand Paper Making. $7(2): 9-15$.

Gilbert M 1966. Servant of India. A Study of Imperial Rule, Longmans; First Edition, 377-378.

Hess JB, Mosjidis JA 2008. Effect of sunn hemp seed inclusion in broiler starter diets on live performance attributes. J. Appl. Anim. Res. 33:105-108.

Hooper PT, Scanlan WA 1977. Crotalaria retusa poisoning of pigs and poultry. Aust. Vet. J. 53:109114.

Javaid MM, Bhan M, Rathinasabapahi B, Chase CA 2012. A non-protein amino acid from Crotalaria juncea foliage with allelopathic potential. American Society for Horticultural Science, Abstract.

Kamil D, Kumar R, Asha S 2009. Effect of green manuring of Crotalaria juncea L. on some soil borne pathogens. Indian phytopath, 62(3): 304-309. 
Karakurt E 2009. Toprak Verimliliği Yönünden Yeşil Gübreler ve Gübreleme. Tarla Bitkileri Merkez Araştırma Enstitüsü Dergisi, 18 (1-2): 48-54.

Lindemann WC, Glover CR 2003. Nitrogen fixation by legumes. New Mexico State University Cooperative Extension Guide A-129.

Mansoer Z, Reeves DW, Wood CW 1997. Suitability of sunn hemp as an alternative late-summer legume cover crop. Soil Sci. Soc. Am. J. 61:246-253.

Marshall AJ 2002. Sunn hemp (Crotalaria juncea) as an organic amendment in crop production. University of Florida, 310p.

Martin JH, Leonard WH, Stamp DL 1976. Principles of field crop production. Macmillan Publishing Co. New York.

Meagher RL, Nagoshi RN, Brown JT, Fleischer SJ, Westbrook JK, Chase CA 2017. Flowering of the cover crop sunn hemp, Crotalaria juncea L. HortScience, 52(7): 986-990.

Morris JB, Chase C, Treadwell D, Koenig R, Cho A, Morales-Payan JP, Murphy T, Antonious GF 2015. Effect of sunn hemp (Crotalaria juncea L.) cutting date and planting density on weed suppression in Georgia, USA. Journal of Environmental Science and Health, Part B, 50(8): 614-621.

Mosjidis JA, Burke JM, Hess JB 2012. The Facts about Sunn Hemp Toxicity. Crop Sci. 52:1469-1474.

Mosjidis JA, Wang ML 2011. Crotalaria. In: C. Kole, editor, Wild crop relatives: Genomic and breeding resources, Industrial Crops. Springer-Verlag Berlin Heidelberg. p.63-69. doi:10.1007/978-3-642-211027_3

National Academy of Science, 1979. Sunnhemp. In: Advisory committee on technology innovation, tropical legumes: Resources for the future. National Academy of Science, Washington, DC. p. 272-278.

Phatak SC, Dozier JR, Bateman AG, Brunson KE, Martini NL 2002. Cover crops and conservation tillage in sustainable vegetable production. In $\mathrm{E}$. van Santen (ed.) Making Conservation Tillage Conventional: Building a Future on 25 Years of Research. Proceedings Annual Southern Conservation Tillage Conference for Sustainable Agriculture 25: 401-403.

Pilbeam DJ, Bell EA 1979. Reappraisal of the free amino acids in seeds of Crotalaria juncea (Leguminosae). Phytochem., 18, 320-321.

Purseglove JW 1981. Leguminosae. In: J.W. Purseglove, editor, Tropical crops: Dicotyledons. Longman Group, Essex, UK. p. 250-254.

Reeves DW, Mansoer Z, Wood CW 1996. Suitability of sunn hemp as an alternative legume cover crop.
Proceedings of the New Technology and Conservation Tillage 96, 125-130. University of Tennessee Agricultural Experiment Station, Jackson, TN, U.S.A.

Ritchey GE, McKee R, Becker RB, Neal WM, Arnold PDD 1941. Crotalaria for forage. Fla. Agric. Exp. Stn. Bull. 361:72.

Romin AE, Fitt RH 1938. The feeding of sunnhemp hay (Crotalaria juncea) as compared with cowpea hay (Vigna catjang) in a fattening ration for bullocks. Rhod. Agric. J. 35:15-19.

Rotar PP, Joy RJ 1983. 'Tropic Sun' sunn hemp, Crotalaria juncea L. Research Extension Series 036 University of Hawaii, Honolulu

Sadhukhan S, Sarkar U 2016. Production of Biodiesel from Crotalaria juncea (Sunn-Hemp) Oil Using Catalytic Trans-Esterification: Process Optimisation Using a Factorial and Box-Behnken Design. Waste Biomass Valor, 7:343-355.

Sarkar SK, Hazra SK, Sen HS, Karmakar PG, Tripathi MK 2015. Sunnhemp in India. Central Research Institute for Jute and Allied Fibres (ICAR), Barrackpore, West Bengal. pp.140.

Schomberg HH, Martini NL, Diaz-Perez JC, Phatak SC, Balkcom KS, Bhardwaj HL 2007. Potential for using sunn hemp as a source of biomass and nitrogen for the Piedmont and Coastal Plain regions of the southeastern USA. Agronomy Journal 99: 1448-1457.

Stallings A 2015. Sunn hemp (Crotalaria juncea L.) as a Cover Crop for Winter Wheat. Graduate Faculty of Auburn University, Master thesis, 144p.

Strickland RW, Lambourne LJ, Ratcliff D 1987. A rat bioassay for screening tropical legume forages and seeds for palatability and toxicity. Aust. J. Exp. Agric. 27:45-53.

Wang K, Sipes BS, Schmitt DP 2002. Crotalaria as a cover crop for nematode management: a review. Nematropica 32: 35-57.

Wang KH, McSorley R, Marshall AJ, Gallaher RN 2004. Nematode community changes following decomposition of Crotalaria juncea amendment in litterbags. Appl. Soil Ecology 27:31-45.

Warren J, Wilson T, Edwards J 2012. Using sunnhemp as a cover crop in Oklahoma. Oklahoma Cooperative Extension Service, PSS-2273.

White GA, Haun JR 1965. Growing Crotalaria juncea, a multi-purpose fiber legume, for paper pulp. Econ. Bot. 19:175-183.

Williams MC, Molyneux RJ 1987. Occurrence, concentration, and toxicity of pyrrolizidine alkaloids in Crotalaria seeds. Weed Sci. 36:476-481. 